\title{
Sistem kendali otomatis mesin penetas telur menggunakan kontroler PID
}

\author{
Mokh. Sholihul Hadi ${ }^{1}$, Syafiq Ubaidilah ${ }^{2}$, Rizky Asillia P. Sari ${ }^{3}$, Dwi Puri Fatmala ${ }^{4}$ \\ 1. Universitas Negeri Malang, Indonesia | mokh.sholihul.ft@um.ac.id \\ 2. Universitas Negeri Malang, Indonesia | syafiqubaidillah1111@gmail.com \\ 3. Universitas Negeri Malang, Indonesia | rasiliaa06@gmail.com \\ 4. Universitas Negeri Malang, Indonesia | dwi1566@gmail.com
}

\begin{abstract}
Abstrak
Mesin penetas telur merupakan salah satu peralatan yang banyak digunakan pada bidang peternakan ungags. Alat ini digunakan untuk meninggkatkan kuantitas penetasan telur. Tingkat keberhasilan penetasan telur menurut Daniel Azhari sekitas 82\% dan 79\%. Kemungkinan presenttasi ini masih dapat ditingkatkan dengan cara pemerataan distribusi temperature yang lebih merata pada alat penetas telur yang digunakan. Pemerataan suhu pada alat penetas telur dapat menggunakan pengendali (penstabil) temperature, dalam pengendalian temperature diperlukan metode PID. PID yaitu sebuah metode yang menggunakan prinsip penguatan proporsional, penguatan integral dan penguatan derivative untuk memperbaiki respon system kendali. Dengan menggunakan PID kita dapat mempertahankan sugu yang akurat sehingga mengurangi kesalahan (error) yang terjadi. Sistem kendali digital berupa control PID berhasil diterapkan pada suhu ruang dengan suhu tertentu dengan set value const int $\mathrm{Sp}=38$, const float $\mathrm{Kp}=2$, const float $\mathrm{Ki}=1.5$, const float $\mathrm{Kd}=1$, const int $T s=100 \mathrm{~ms}$. Kontrol suhu stabil untuk penetasan telur dengan pembalikan telur secara berkala sesuai dengan spesifikasi pengeraman ayam sudah dapat diterapkan dengan kestabilan suhu dengan kisaran $37-39^{\circ} \mathrm{C}$.
\end{abstract}

Kata Kunci

Penetas telur, Temperatur, PID, Arduino

TEKNO Vol. 27 Issue 2, p116-124 | Jurusan Teknik Elektro, Universitas Negeri Malang, Indonesia | September 2017 M.S. Hadi, S. Ubaidilah, R.A. Puspitasari, D.P. Fatmala | Sistem Kendali Otomatis Mesin Penetas Telur Menggunakan ... 
http://journal2.um.ac.id/index.php/tekno | ISSN 1693-8739

\section{Pendahuluan}

Seiring perkembangan dan pertumbuhan penduduk yang sangat cepat di Indonesia ini berdampak pada tingkat konsumsi masyarakat meningkat, pada khususnya akan kebutuhan daging unggas maupun telurnya yang kaya akan sumber protein utama (Maskuri, 2005). Hal itu harus diimbangi dengan persediaan yang cukup untuk memenuhi ketersediaan pangan, sehingga ketahanan pangan yang mengandung protein tinggi tetap terpenuhi (Yudhi, 2012). Salah satu jalan untuk mengatasinya yaitu dengan menggantikan peran mesin penetas telur konvensional yang ditingkatkan kemampuannya menjadi mesin penetas telur yang otomatis sehingga dalam proses penetasan telur menjadi lebih mudah, hemat, dan praktis dengan hasil penetasan yang lebih baik (Fadlika, Erwin, Rahmat, Hendi H, 2014). Penelitian ini bertujuan untuk mendesain sistem monitoring temperatur dan kelembaban mesin penetas telur yang otomatis dengan menggunakan modul sensor LM35 (National Semiconductor). Sistem sensor yang digunakan berbasis pada sifat polimer kapasitif untuk sensor kelembaban dan bandgap untuk sensor temperatur. Seluruh aktifitas pengontrolan sistem dilakukan oleh arduino uno. Seluruh aktivitas dari sistem tersebut dikontrol secara On-Off untuk mengontrol suatu mesin penetas telur secara otomatis oleh mikrokontroler. Dengan kontroler tersebut diharapkan bisa didapatkan pengontrolan suhu dan kelembaban yang diinginkan sehingga dapat menetaskan telur menjadi bibit ayam yang berkualitas unggul.

\section{Metode}

Metode penelitian yang dipakai adalah metode experiment. Mikrokontroller digunakan untuk menstabilkan suhu untuk penetasan telur. Alat diset dengan suhu $38^{\circ} \mathrm{C}$ yang digunakan untuk menghangatkan telur, pada saat suhu dalam box lebih dari $38^{\circ} \mathrm{C}$ secara otomatis lampu akan mati (secara analog) dan akan menyala kembali jika suhu dibawah $38^{\circ} \mathrm{C}$ lampu akan secara otomatis bertambah terang.

Penetasan telur pada alat ini diset selama 21 hari, data selama 21 hari ini akan ditmpilkan pada LCD. Pada LCD akan menampilkan data besar suhu, tanggal, bulan, tahun, dan jumlah hari selama penetasan telur. Selama penetasan telur berlangsung telur akan berputar $180^{\circ}$ setiap 6 jam sekali. Selama penetasan telur jika terdapat telur yang menetas akan dideteksi gerakannya dengan sensor PIR. Jika pada sensor PIR mendeteksi benda maka logika akan berubah dari 0 menjadi satu dan buzzer akan menyala. Menyalanya buzzer dapat digunakan untuk menandai adanya telur yang menetas. Perancangan pada sistem terdiri dari 3 perancangan, yaitu:

1. Perancangan Perangkat Lunak

a. Perancangan program 




Gambar 1. Flowchart Program Penetas Telur

2. Perancangan Sistem Kendali

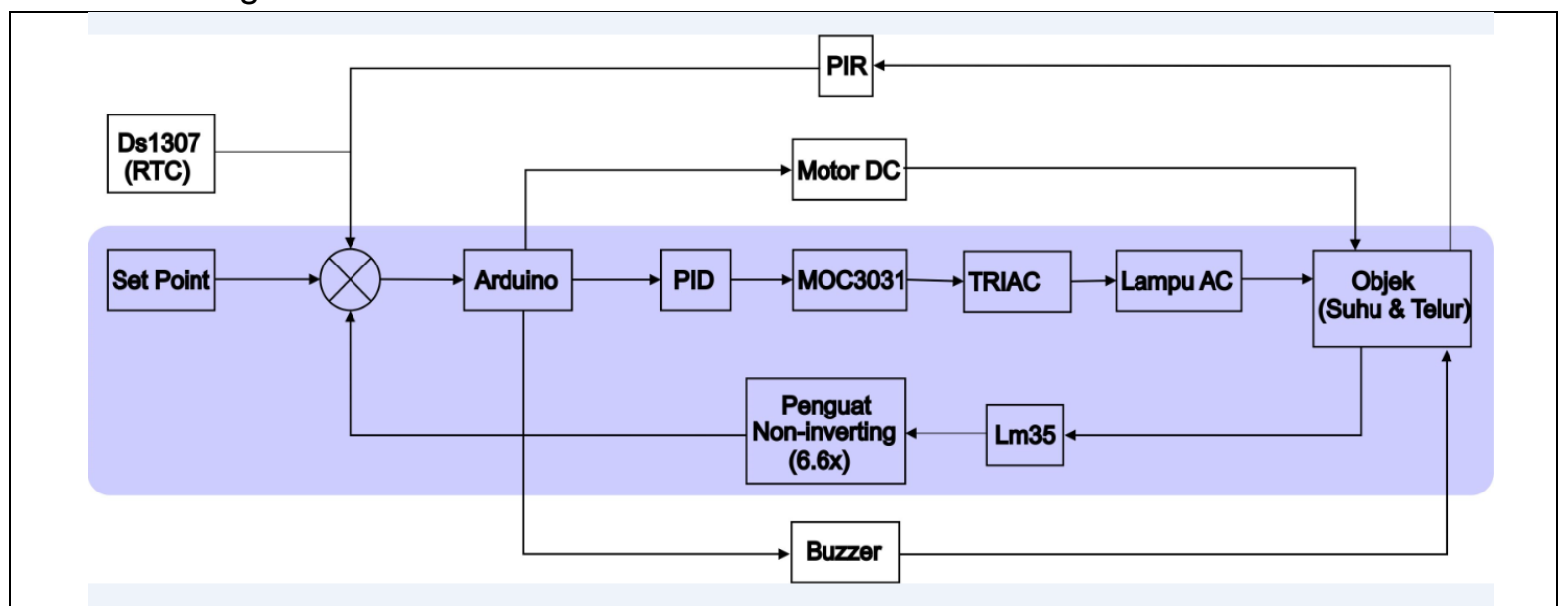

Gambar 2. Blok diagram Sistem Kendali

TEKNO Vol. 27 Issue 2, p116-124 | Jurusan Teknik Elektro, Universitas Negeri Malang, Indonesia | September 2017 M.S. Hadi, S. Ubaidilah, R.A. Puspitasari, D.P. Fatmala | Sistem Kendali Otomatis Mesin Penetas Telur Menggunakan ... 
Pada daerah berwarna abu-abu menunjukkan daerah kerja PID dimana controller menggunakan Arduino UNO R3. Output PID kemudian digunakan untuk mengontrol lampu AC 220Volt/25Watt dengan control AC menggunakan TRIAC Q4008T dengan driver control MOC3031. Driver MOC3031 bekerja berdasarkan tegangan input yang diberikan oleh PID berupa sinyal PWM. Hasil dari control lampu AC menghasilkan panas yang digunakan untuk mengontrol suhu ruangan incubator. Suhu ruangan kemudian diukur oleh sensor LM35 yang dikuatkan dengan penguat non-inverting menggunakan IC LM324,dimana output LM324 digunakan sebagai feddback untuk proses PID pada siklus selanjutnya (Gerry, 2005)

Selain kontrol PID, pada gambar background putih menunjukkan perangkat yang tidak digunakan untuk PID. Sensor PIR digunakan untuk mendeteksi apabila telur sudah menetas. Ketika telur sudah menetas, maka sensor PIR akan mendeteksi inframerah dari anak ayam sehingga sensor berlogika 1. Ketika sensor berlogika 1, maka Arduino akan mengirim sinyal ke buzzer sehingga buzzer menyala.

Sedangkan komponen lain yaitu DS1307 dan motor DC. Fungsi dari DS1307 adalah untuk menampilkan tanggal dan hitungan timer untuk memutar motor DC dimana motor DC digunakan untuk memutar telur agar setiap sisi telur mendapatkan proses inkubasi yang merata dan telur dapat menetas.

\section{Perancangan Perangkat Keras}



Gambar 3. Desain penempatan komponen pada incubator telur 
http://journal2.um.ac.id/index.php/tekno | ISSN 1693-8739

\section{Perancangan Sistem Elektrik}

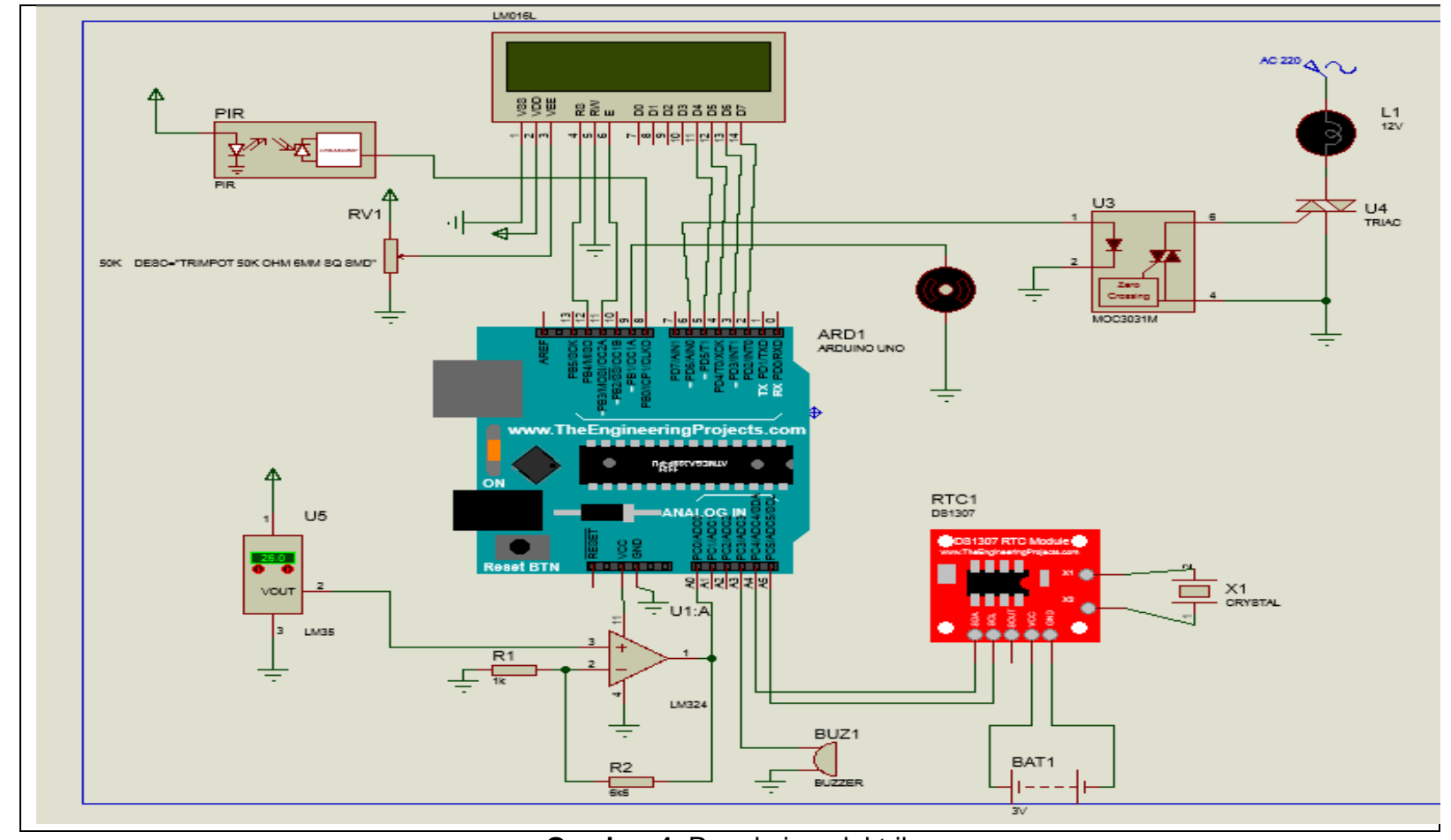

Gambar 4. Rangkaian elektrik

\section{Hasil}

Dalam pengujian alat yang telah dirancang bertujun untuk mengetahui berfungsi tidaknya alat yang sudah dirancang meliputi nyala lampu bohlam ketika suhu yang ada di dalam box penetas telur melebihi atau kurang dari data suhu yang dimasukkan pada program alat, mengetahui pembalik telur yang dilakukan oleh stik penopang telur yang dijalankan oleh motor yang berputar sesuai data yang telah dimasukkan pada program alat yaitu setiap 6 jam sekali berputar $180^{\circ}$ dan untuk mengetahui fungsi dari sensor PIR yang digunakan pada alat untuk mengetahui apakah terdapat telur yang sudah menetas atau belum serta untuk mengetahui tampilan data yang ditampilkan pada LCD, pada ICD yang berfungsi dengan baik sesuai dengan setting data pada program alat akan menampilkan basar suhu di dalam box, tanggal bulan tahun dan jumlah hari selama proses pengeraman telur di dalam box penetas telur.

\section{Pengujian Sensor LM35}

Proses pengujian menggunakan kotak pengeraman sebagai tempat proses berlangsungnya pemanasan untuk mengisolasi panas dari lingkungan luar. Sebelum dilakukan pengujian terhadap alat yang dirancang, terlebih dahulu dilakukan pengambilan data terhadap sensor LM35 yang akan digunakan. Data yang diambil adalah hasil pengukuran keluaran tegangan sensor LM35 dibandingkan hasil pengukuran suhu dalam kotak pengeraman. Data ini diperlukan untuk membuat persamaan dalam menkonversi nilai tegangan yang diterima ADC mikrokontroler menjadi nilai suhu yang nanti akan di tampilkan 
http://journal2.um.ac.id/index.php/tekno | ISSN 1693-8739

pada LCD. Data ini diambil dengan dua cara yaitu ketika suhu dinaikkan dan ketika suhu diturunkan.

Table 1. Hasil Pengujian Sensor LM 35

\begin{tabular}{ccl}
\hline Suhu $\left({ }^{0} \mathrm{C}\right)$ & $\begin{array}{c}\text { Tegangan Keluaran } \\
(\mathrm{V}) \text { pada LM35 }\end{array}$ & Lampu Bohlam \\
\hline 28 & 0.28 & Menyala \\
\hline 35 & 0.35 & Menyala \\
\hline 36 & 0.40 & Menyala \\
\hline 37 & 0.45 & Menyala \\
\hline 38 & 0.51 & Menyala \\
\hline 39 & 0.55 & Mulai redup \\
\hline 40 & 0.61 & Redup \\
\hline
\end{tabular}

Dari hasil pengujian diketahui tegangan keluaran dari LM 35 naik sebesar 50mV untuk setiap $5^{\circ} \mathrm{C}$ atau $10 \mathrm{mV} /{ }^{\circ} \mathrm{C}$, maka dapat dikatakan sensor dapat bekerja dengan baik sesuai dengan yang diinginkan.

2. Tuning Nilai pada PID

Pada pengujian nilai $\mathrm{Sp}, \mathrm{Kp}, \mathrm{Ki}, \mathrm{Kd}$, dan Ts dilakukan dengan trial and error sehingga pada pensettingan nilai ini membutuhkan banyak percobaan. Pada percobaan ini didapat nilai yang sesuai, seperti ditunjukkan dalam Tabel 2 .

Tabel 2. Setting Nilai

\begin{tabular}{l|l}
\hline Nama & Nilai \\
\hline $\mathrm{Sp}$ & 38 \\
\hline $\mathrm{Kp}$ & 2 \\
\hline $\mathrm{Ki}$ & 1.5 \\
\hline $\mathrm{Kd}$ & 1 \\
\hline $\mathrm{Ts}$ & $100 \mathrm{~ms}$ \\
\hline
\end{tabular}

3. Pengujian Respon Sinyal pada PID

Pada pengujian respon sinyal PID yang terjadi pada alat ini yaitu I-Incubator terdapat 4 bagian respon sinyal, yaitu transien naik, transien turun, menuju steady state, steady state.

a. Transien Naik

Proses dimana system bekerja mulai dari keadaan awal (suhu standart) menuju set point (suhu yang diinginkan). Pada keadaan ini terdapat simpangan positif antara set point dengan present value. Semakin dekat present value dengan set point maka simpangan positif semakin kecil sehingga keadaan merata. 


\section{TEKNO Jumal Teknologi, Elektro, dan Keivuruan}

http://journal2.um.ac.id/index.php/tekno | ISSN 1693-8739

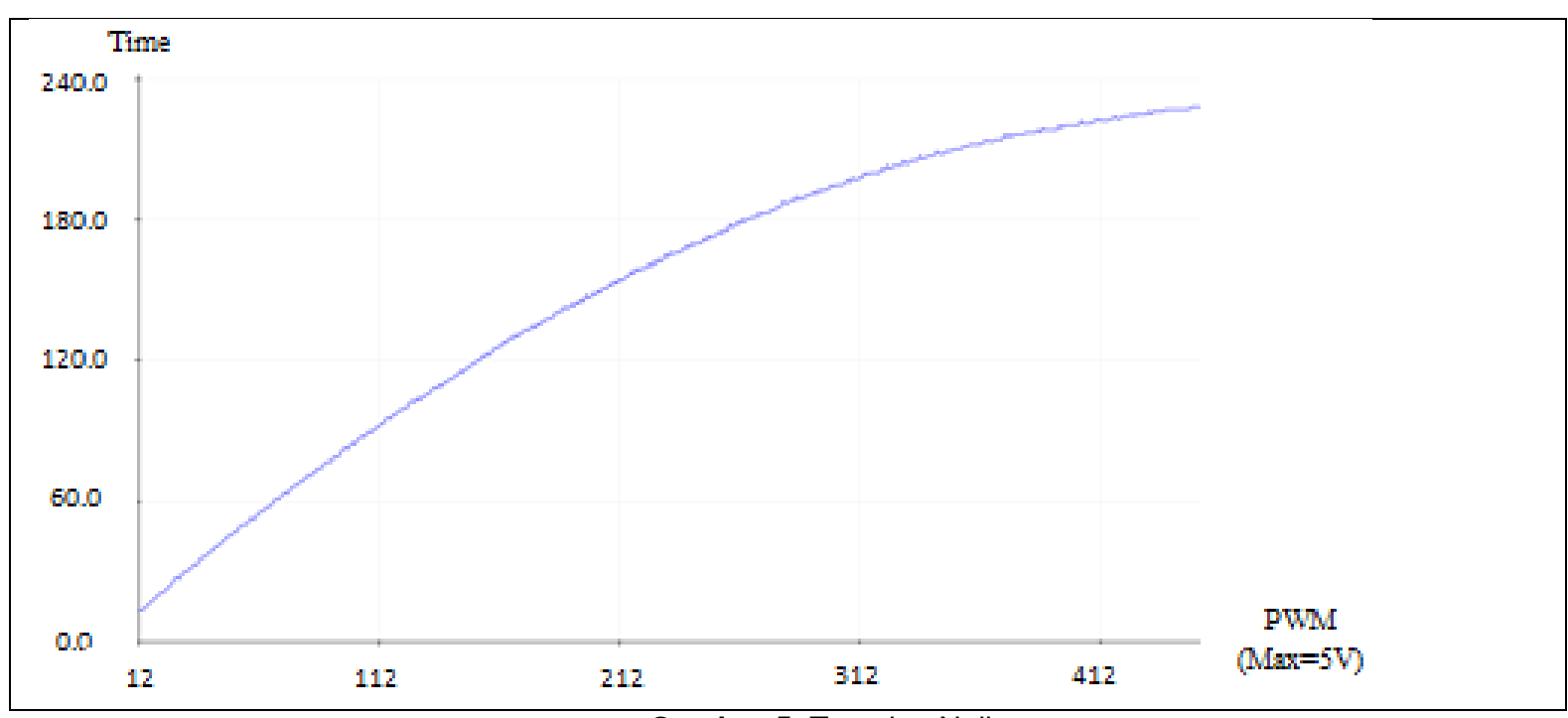

Gambar 5. Transien Naik

b. Transien Turun

Pada proses ini terjadi ketika present value sedikit melewati set point sehingga simpangan menjadi negative yang menyebabkan output semakin berkurang bahkan mati. Ketika present value berada di bawah atau kurang dari set point maka simpangan menjadi positif sehingga output akan bertambah panas kembali.

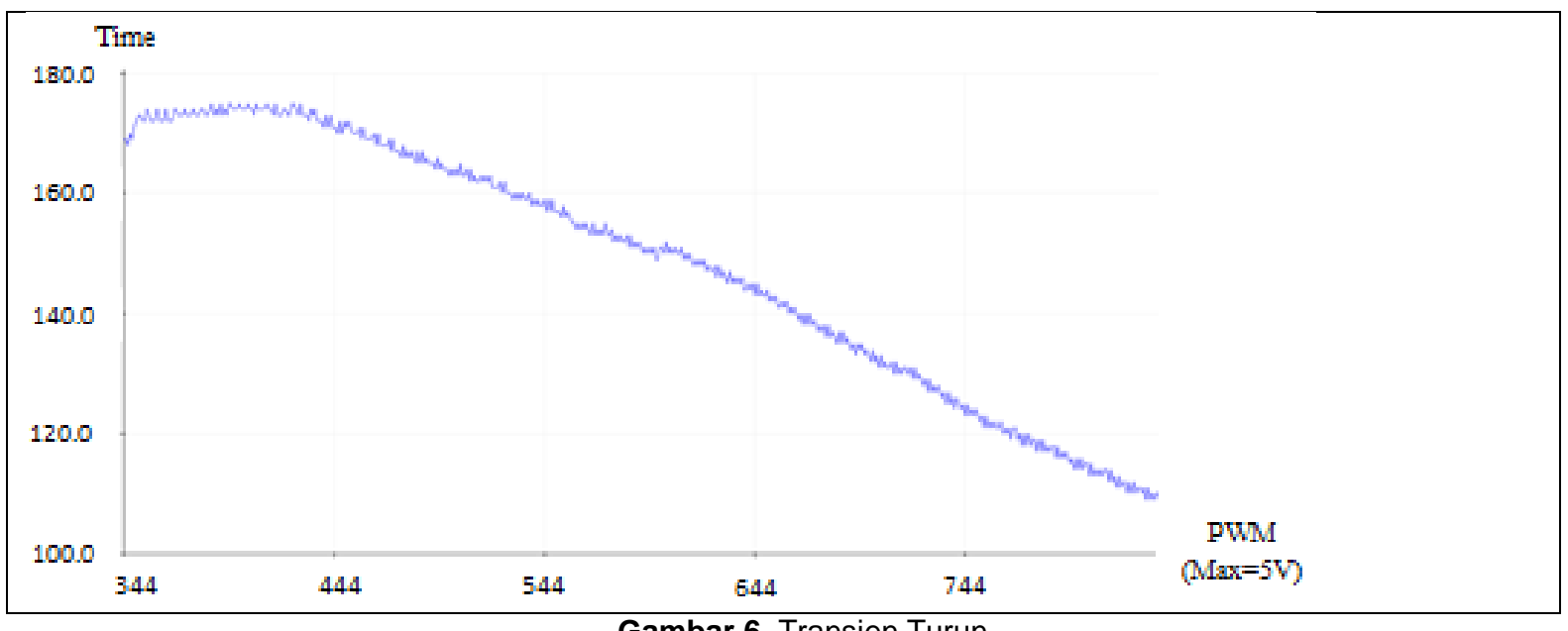

Gambar 6. Transien Turun

c. Menuju Stedy State 


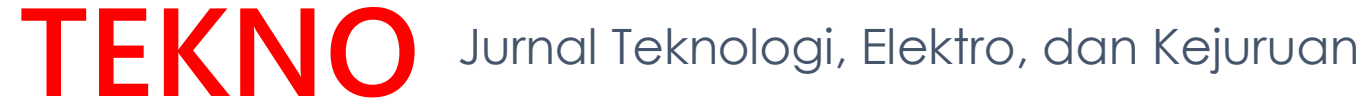

http://journal2.um.ac.id/index.php/tekno | ISSN 1693-8739

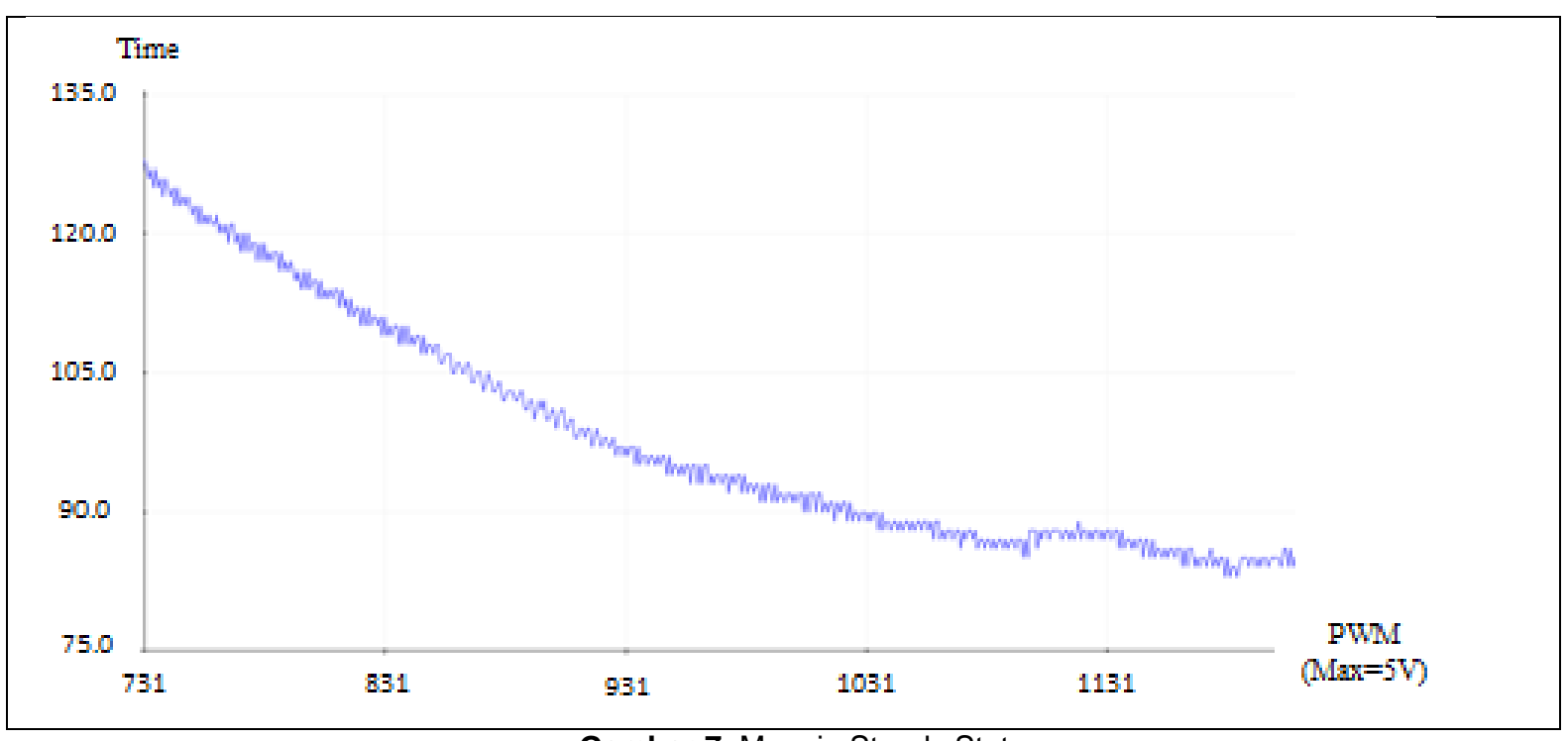

Gambar 7. Menuju Steady State

Pada proses ini merupakan kelanjutan dari proses sebelumnya dimana present value hampir sama dengan set point. Keadaan ini akan terus berlanjut hingga tidak ada simpangan atau simpangan sangat kecil antara present value dengan set point.

\section{d. Steady State}

Keadaan ini adalah keadaan mantab dimana nilai present value memiliki simpangan yang sangat kecil dengan set point sehingga sinyal output yang diberikan hampir lurus. Keadaan ini akan terus berlanjut hingga proses di hentikan (catu daya di lepas).



Gambar 8. Steady State 
Hasil percobaan alat menunjukkan kesesuaian dengan target yang diharapkan dimana pengaturan suhu berjalan dengan baik yaitu pada keadaan steady state suhu ruang berkisar antara 37-39 derajat celcius (sesuai dengan spesifikasi suhu pengeraman telur). Keadaan ini terjadi ketika setting SP 38, nilai KP 2, nilai KI 1.5 dan nilai KD 1. Hal itu terjadi karena ketika suhu menunjukkan angka kurang dari SP, maka kombinasi KP, KI dan KD akan mengurangi output PWM pada MOC3031. Sedangkan ketika suhu kurang dari SP, maka kombinasi KP, KI dan KD akan menambah output PWM MOC3031 sehingga akan terus berjalan stabil pada suhu 37-39 derajat celcius. Sedangkan untuk mekanik pembalik, telur berputar setiap 30 detik sekali sebesar 90 derajat (sesuai dengan spesifikasi putaran telur ideal). Ini terjadi ketika detik rtc meunjukkan angka 0 dan 30 maka motor akan berputar sebanyak 500 ms. Akan tetapi ketika ingin menggunakan spesifikasi ideal incubator, putaran digunakan 6 jam sekali. Hal itu dapat diatur pada kode program bagian operasi kondisi bagian motor DC (mekanik).

\section{Kesimpulan}

Dari percobaan alat yang teah dilakukan, dapat disimpulkan bahwa:

1. Sistem kendali digital berupa control PID berhasil diterapkan pada suhu ruang dengan suhu tertentu dengan set value const int $\mathrm{Sp}=38$, const float $K p=2$, const float $K \mathbf{i}=\mathbf{1 . 5}$, const float $\mathrm{Kd}=\mathbf{1}$, const int $\mathbf{T s}=\mathbf{1 0 0 \mathrm { ms } \text { . }}$

2. Desain dan alat penetas telur cerdas full automatic meliputi kiontrol suhu dan pembalik telur secara berkala dapat dijalankan dengan secara otomatis PID memanfaatkan driver TRIAC sebagai pengendali lampu AC 220 Volt/25 watt menggunakan control PWM aurduino UNO.

3. Kontrol suhu stabil untuk penetasan telur dengan pembalikan telur secara berkala sesuai dengan spesifikasi pengeraman ayam sudah dapat diterapkan dengan kestabilan suhu dengan kisaran 37-39 derajat celcius. putaran motor mekanik menggunakan gearbox motor DC.

\section{Daftar Rujukan}

Maskuri. 2005. Pengendali Suhu Alat Penetas Telur Ayam Berbasis Mikrokontroler AT89C51. Demak: Jurnal UNISFAT. 1 September 2005 Hal 55-66.

Yudhi Gunardi. Perancangan dan Pembuatan Penetas Telur Berbasis Arduino Dumilanove. Jakarta: Prosiding SNPPTI 2012.

Fadlika, Erwin, Rahmat, Hendi H. 2014. Pengendalian Suhu Berbasis Mikrokontroler Pada Ruang Penetas Telur. Bandung: Jurnal Reka Elkomika. Vol. 2 No. 4.

National Semiconductor. LM35A/ LM35C/LM35CA/LM35D Precision Centigrade Temperature Sensors.

Gerry, John. 2005. Adaptive Tunning-Expectations and Limitations. ExperTune Inc. 